Ex.11n

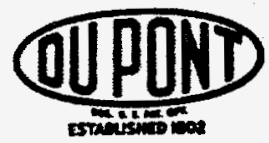
\section{E. 1. DU PONT de Nemours \& Company}

Copy 1 - J. B. Tinker

2 - K. W. Nillett - T. C. Evans - SRP

3 - M. H. Wahl - SRL

$4-$ D. W. Bartholomew

WILMINGTON, DELAWARE

EXPLOSIVES DEPARTMENT

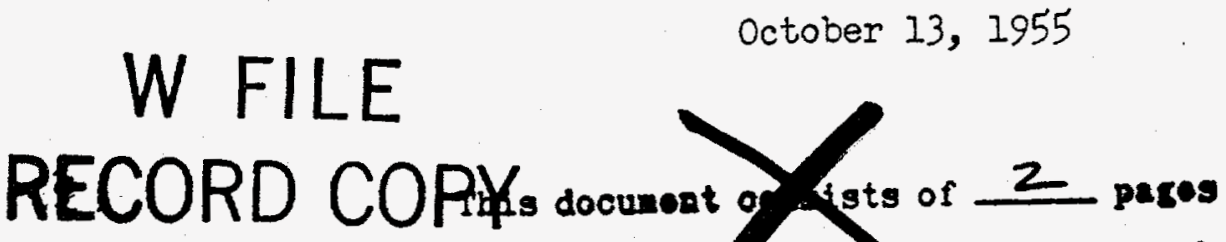

SR/ $\frac{D W-55-16-35}{\text { IN TURN TO: }}$

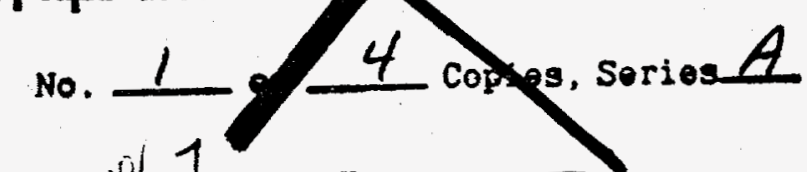

1. J. B. Tinker
2. J. E. Col Elassiflcation Cancolled/Changhn

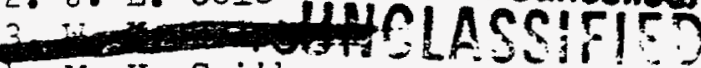

4. M. H. Smith

$\div$ A Authority of

6. H. Worthington

7. S. A. McYeight

8. W File

FROM

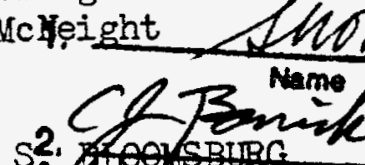

rec.
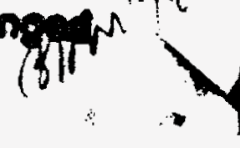
WEEKIY REPORT, OCTOBER 7-13? 195 swiewing 300-M AREA - SAVANNAH RIVER PIAN

I. TTEMS REQUESTED OF ENGINEERING

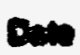

DOES NOT CONTAIN Tros $\frac{1 / 23 / 89}{0+10 / 3}$ UNCLASSIFIED CONTROLLED NUCLEAR INFORMATION

A review of progress to date on design of a production prototype pneumatic pressing autoclave and on production facilities for fabrication of Nark III and Mark V fuel elements will be presented by Ingineering on Monday afternoon, October 17.

II. ITIUS OF INIEREST

\title{
HF Program
}

Forty hot pressed 1.138n diameter hollow slugs were shipped this week from Sylvania to SRP for evaluation. Preliminary inspections on four of these slugs have shown that SEP has made marked progress toward eliminating most of the defects observed in previous shipments. Adverse comments on this prelinitinary examination are as follows:

I. Grain growth in the aluminum cap and spire was again observed.

2. Thin hydride type layer ranging from 0.1 to 0.5 mils in thickness on two of the slugs examined.

3. Only one case of uranium diffusion into the alumimm can wall in a small area at the end of a slug.

Some minor folding at the spire bottom and at the cap was observed but this appears to be of no significant consequence. Thinning of the can wall at the top and bottom of the can was also minor and does not appear to be a problem. A small mmer of inclusions were detectable at 


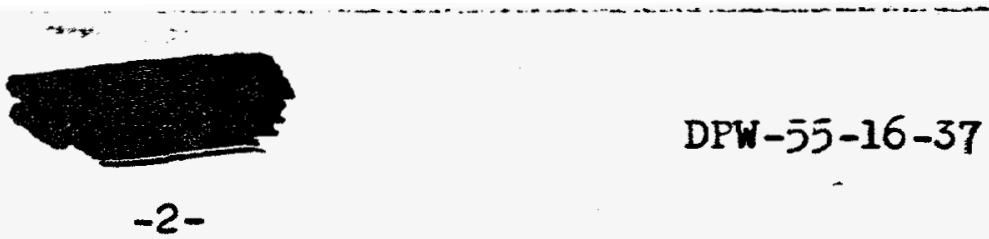

for SEP have been placed with Fernald this week with requested deliveries between Nov. I and Dec. 1 of this year. Requests for procurement of 50,000 Savannah hollow cores and 12,000 Sylvania are currently belng made to SROO; delivery dates on these latter orders will be specified later on the basis of unit prices for the current machining capacity of $15,000 \mathrm{pcs}$ / month and for increasing ALBA machining capacity to 50,000 pes. per month.

The 2,000 Sylvania cores which Fernald is to supply by Dec. 1 will be beta transformed horizontally at FMPC in the form of $22 \mathrm{ft}$. rods, then water quenched (after 20 seconds required to make the transfer from the salt to the water). This treatment was specifled because any other form of heat treatment would involve some degree of change in Fernald production equipment with a consequent extension of both delivery and price.

\section{DISCLAIMER}

This report was prepared as an account of work sponsored by an agency of the United States Government. Neither the United States Government nor any agency thereof, nor any of their employees, makes any warranty, express or implied, or assumes any legal liability or responsibility for the accuracy, completeness, or usefulness of any information, apparatus, product, or process disclosed, or represents that its use would not infringe privately owned rights. Reference herein to any specific commercial product, process, or service by trade name, trademark, manufacturer, or otherwise does not necessarily constitute or imply its endorsement, recommendation, or favoring by the United States Government or any agency thereof. The views and opinions of authors expressed herein do not necessarily state or reflect those of the United States Government or any agency thereof. 


\title{
DISCLAIMER
}

\author{
Portions of this document may be illegible \\ in electronic image products. Images are \\ produced from the best available original \\ document.
}

